\title{
Pemanfaatan Ragam Aplikasi Seluler Antikorupsi dalam Upaya Pencegahan Korupsi
}

\author{
Ipi Maryati Kuding, Irwansyah \\ Universitas Indonesia \\ Jl. Salemba Raya No. 4 Jakarta Pusat 10430, Indonesia \\ ipi.maryati@gmail.com; dr.irwansyah.ma@gmail.com
}

Masuk tanggal : 14-07-2020, revisi tanggal : 10-11-2020, diterima untuk diterbitkan tanggal : 11-11-2020

\begin{abstract}
The industrial revolution brings benefits and challenges to every country involved in this transformation. The industrial revolution 4.0 has created an interconnection between all things and the internet so that it can send and receive data. The government is trying to adapt to this development, one of which is done by implementing open government commitments. In the concept of open government, open data is important as a form of openness and accountability of government. In realizing open government, the government is currently starting to implement $m$ Gov technology which provides a service system based on cellular application technology that is able to offer easy access, availability, is more dynamic, and is able to increase citizen participation. This paper discusses mobile applications launched by the Corruption Eradication Commission (KPK) as a means of socialization, anti-corruption education as well as opening spaces for participation and collaboration with all levels of society. Through these mobile applications the KPK also encourages the public to monitor public services and invites the public to take advantage of the information available on anti-corruption platforms and applications for advocacy purposes and convey the aspirations of the public to the government. This study uses the use and gratification theory, by interviewing 4 informants regarding their experiences using applications and as a management team. This study aims to determine the use of various mobile applications in fulfilling information needs in increasing public understanding and participation in preventing corruption. The research approach used is a qualitative approach with a case study method. The findings in the study indicate a positive response from application users to Android and iOS-based mobile applications launched by the KPK. From the user side, the anti-corruption mobile application is able to meet the needs, especially the ease of access that is not bound by time and space. However, development is still needed for these applications, both in terms of appearance, the value of content benefits, data reliability and how to use the content to prevent corruption.
\end{abstract}

Keywords: anti-corruption, industrial revolution 4.0, mobile applications, open data, open government

\begin{abstract}
Abstrak
Revolusi industri membawa manfaat dan tantangan bagi setiap negara yang terlibat dalam transformasi tersebut. Revolusi industri 4.0 telah membuat interkoneksi antara semua hal dengan internet sehingga dapat mengirim dan menerima data. Pemerintah berupaya beradaptasi dengan perkembangan ini yang salah satunya dilakukan dengan implementasi komitmen open government. Dalam konsep open government, open data penting sebagai wujud keterbukaan dan akutanbilitas pemerintahan. Dalam mewujudkan open government pemerintah saat ini mulai menerapkan teknologi mGov yang menyediakan sistem layanan berbasis teknologi aplikasi selular yang mampu menawarkan kemudahan akses,
\end{abstract}


ketersediaan, lebih dinamis, dan mampu meningkatkan partisipasi warga. Tulisan ini membahas tentang aplikasi-aplikasi seluler yang diluncurkan oleh Komisi Pemberantasan Korupsi (KPK) sebagai sarana sosialisasi, edukasi antikorupsi sekaligus membuka ruang partisipasi dan kolaborasi dengan seluruh lapisan masyarakat. Melalui aplikasi-aplikasi mobile tersebut KPK juga mendorong masyarakat untuk memonitor layanan publik serta mengajak masyarakat untuk memanfaatkan informasi yang tersedia dalam platform dan aplikasi antikorupsi untuk tujuan advokasi serta menyampaikan aspirasi dari masyarakat kepada pemerintah. Penelitian ini menggunakan teori penggunaan dan pemenuhan kebutuhan (uses and gratification theory) dengan mewawancarai 4 informan terkait pengalamannya menggunakan aplikasi dan sebagai tim pengelola. Penelitian bertujuan untuk mengetahui pemanfaatan ragam aplikasi seluler dalam pemenuhan kebutuhan informasi dalam meningkatkan pemahaman dan partisipasi masyarakat dalam pencegahan korupsi. Pendekatan penelitian yang digunakan adalah pendekatan kualitatif dengan metode studi kasus. Temuan dalam penelitian mengindikasikan respon positif pengguna aplikasi terhadap aplikasi-aplikasi seluler berbasis android dan iOS yang diluncurkan oleh KPK. Dari sisi pengguna, aplikasi seluler antikorupsi mampu memenuhi kebutuhan khususnya kemudahan dalam akses yang tidak terikat ruang dan waktu. Namun demikian, masih diperlukan pengembangan untuk aplikasi-aplikasi tersebut, baik terkait tampilan, nilai manfaat konten, keterandalan data dan bagaimana memanfaatkan konten tersebut untuk pencegahan korupsi.

Kata Kunci: antikorupsi, aplikasi seluler, data terbuka, industri 4.0, pemerintahan terbuka, revolusi industri 4.0

\section{Pendahuluan}

Undang-Undang No 31 Tahun 1999 tentang Pemberantasan Tindak Pidana Korupsi dalam pertimbangannya menyebutkan bahwa tindak pindana korupsi sangat merugikan keuangan negara atau perekonomian negara dan menghambat pembangunan nasional. Akibat tindak pidana korupsi selain merugikan keuangan negara atau perekonomian negara, juga menghambat pertumbuhan dan kelangsungan pembangunan nasional yang menuntut efisiensi tinggi. Karenanya, pemberantasannya harus dilakukan secara luar biasa. Korupsi juga berdampak sangat serius bagi kehidupan masyarakat dan negara. Dampak yang ditimbulkan bersifat masif, sehingga tindakan korupsi dikategorikan sebagai kejahatan luar biasa (extra ordinary crime) setara dengan kejahatan pembunuhan masal (Manara, 2016). Berdasarkan data yang dilansir oleh Transparancy International, posisi Indonesia saat ini berada pada urutan 85 dari 180 negara yang disurvei berdasarkan tingkat bersih dari korupsi. Indonesia mendapat skor 40 yang menempatkan Indonesia terkategori sebagai negara yang korup. Ini artinya korupsi masih menjadi persoalan besar bangsa ini.

Dalam pengertian korupsi disebutkan bahwa pemberantasan tindak pidana korupsi dilakukan dengan dua pendekatan, yaitu pencegahan dan penindakan. Melalui pendekatan pencegahan inilah peran masyarakat sangat vital. Pencegahan korupsi dapat dilakukan dengan cara menguatkan faktor internal agar individu tidak tergoda untuk korupsi. Salah satu akar penyebabnya karena rendahnya integritas diri, sehingga internalisasi nilai antikorupsi dapat dilakukan melalui penanaman nilai integritas. Harapanya dengan integritas yang dimiliki, individu dapat 
Ipi Maryati Kuding, Irwansyah: Pemanfaatan Ragam Aplikasi Seluler Antikorupsi dalam Upaya Pencegahan Korupsi

mengendalikan faktor eksternal penyebab korupsi. Upaya penanaman nilai integritas dapat dilakukan melalui jalur pendidikan. Internalisasi nilai integritas dalam pendidikan sebaiknya dilakukan sedini mungkin (Sukadari, Komalasari, \& Wihaskoro, 2018). Korupsi juga terjadi karena ketertutupan dan ketiadaan transparansi. Menyadari hal ini pemerintah Indonesia pada 2011 bersama 7 negara lainnya membentuk sebuah gerakan global yang mendorong komitmen keterbukaan pemerintah di dunia. Gerakan tersebut dikenal dengan open government partnership (OGP) (Soegiono, 2017). Ini merupakan titik awal yang menandai perjalanan Indonesia menjadi pemerintahan yang lebih terbuka dan berupaya meningkatkan transparansi, partisipasi dan kolaborasi dengan publik.

Pemerintah dengan komitmen keterbukaan tersebut telah berupaya membuka dan memperluas akses informasi tentang pemerintah dan pada saat yang sama mendorong partisipasi masyarakat untuk memanfaatkan data dan informasi tentang pemerintah untuk melahirkan kolaborasi antara pemerintah dan masyarakat, khususnya terkait layanan publik yang menjadi hak masyarakat. Karena pada hakikatnya open government dilandasi beberapa prinsip, yaitu keterbukaan, partisipasi dan kolaborasi (Harrison et al., 2011). Aspek penting dari konsep open government adalah open data. Open data memungkinkan pengguna tidak hanya mengakses data yang tersedia secara daring, namun juga memungkinkan pengguna untuk melakukan analisis, menggunakan data tersebut hingga mendiseminasikan kembali data tersebut (Soegiono, 2017). Kemampuan open data untuk diunduh, diolah dan dibagikan akan mendorong pelibatan dan kolaborasi antara pemerintah dan pengguna data. Ketika pemerintah telah membuka akses informasi dan data kepada publik, maka semakin meningkat pengawasan publik terhadap jalannya pemerintahan. Semakin baik kualitas keterbukaan open data pada sebuah negara, maka semakin positif indeks persepsi korupsi sebuah negara.

Di era teknologi informasi saat ini, open data menjadi kebutuhan yang tidak terhindarkan. Pelibatan masyarakat dalam pengawasan jalannya pemerintah semakin dimudahkan. Terutama dengan hadirnya internet yang telah mengubah hampir seluruh aspek kehidupan, telah menggeser pola konsumsi dan pencarian informasi. Demikian juga pola interaksi dan sosialisasi yang telah bergeser dari ruang-ruang publik ke ruang virtual. Ditambah dengan hadirnya teknologi telepon seluler pintar atau yang dikenal dengan smartphone. Gawai pintar tersebut yang terhubung dengan internet telah memindahkan seisi dunia dalam genggaman. Tidak ada lagi sekat ruang dan waktu untuk mengakses informasi dan data yang berada di belahan dunia lain. Hadirnya teknologi seluler semakin menghubungkan antar manusia dan mempermudah berbagai aspek kehidupan. Secara langsung mendorong peningkatan produktifitas, menjembatani sumber produksi kepada pusat konsumsi (Harris \& Cooper, 2019). Tidak terkecuali di negara maju, penggunaan smartphone telah meningkatkan kualitas kehidupan manusianya. Dampak dari tren penggunaan teknologi seluler dirasakan di setiap aspek kehidupan, baik dalam dunia bisnis hingga ke sektor pendidikan. Institusi pendidikan tinggi di berbagai daerah menjadi lebih sadar dan mulai merespon kebutuhan penggunaan serta akses seluler dalam dunia pendidikan. Teknologi 
selular telah diidentifikasi sebagai salah satu "tren utama" teratas sejak 2006 (Wong, 2012).

Dalam perkembangannya pemanfaatan aplikasi berbasis seluler tidak hanya digunakan kalangan bisnis dan pendidikan. Badan-badan publik penyelenggara layanan publik, tidak ketinggalan memanfaatkan teknologi seluler dalam memberikan pelayanan yang lebih informatif, komunikatif dan murah. Sebagai upaya pencegahan korupsi yang mendorong transparansi dengan membuka data, KPK meluncurkan platform Jaringan Pencegahan korupsi atau JAGA dan aplikasi daring antikorupsi lainnya yang berbasis mobile. KPK bekerja sama dengan kementerian dan lembaga menyajikan data seputar informasi pelayanan publik yang dimiliki oleh masing-masing kementerian dan lembaga tersebut. Berdasarkan pemanfaatan teknologi tersebut, penting bagi peneliti untuk melihat bagaimana pemanfaatan aplikasi-aplikasi seluler antikorupsi yang dimiliki KPK dalam upaya pencegahan korupsi, Oleh karena itu, penelitian ini berupaya mengidentifikasi "bagaimana pemanfaatan ragam aplikasi seluler untuk pemenuhan kebutuhan informasi dalam meningkatkan pemahaman dan partisipasi masyarakat dalam pencegahan korupsi."

Tidak hanya KPK, badan publik lainnya juga telah memanfaatkan teknologi seluler ini untuk memberikan layanan publik kepada masyarakat. Sebagai contoh, aplikasi PolisiKu milik Polri yang merupakan aplikasi daring pertama Polri untuk meningkatkan layanan keamanan terhadap masyarakat Indonesia. Penelitian yang ditulis oleh Tyan Ludiana Prabowo dan Irwansyah (2018) dalam Jurnal Media Komunikasi Digital PolisiKu: Pelayanan Publik Polri kepada Masyarakat tersebut membahas tentang pemanfaatan aplikasi daring dalam pemberian layanan publik dengan interkoneksi kepada beragam layanan seperti SKCK, SIM Online dan lain sebagainya (Prabowo \& Irwansyah, 2018). Aplikasi tersebut meski belum diterapkan secara nasional, telah memanfaatkan teknologi digital dalam memberikan layanan publik kepada masyarakat hingga menerima pengaduan dari masyarakat.

Dalam jurnal Mobile Apps as Government Communication Media in Urban Public Services: Case Study - The Usage of Qlue Application by Jakarta Provincial Government yang ditulis oleh M. Shendy Adam Firdaus, Irwansyah, dan K. Djaja (2016), tentang pemanfaatan aplikasi Qlue oleh pemerintah Provinsi DKI Jakarta untuk berkomunikasi dengan masyarakat. Hasil penelitian menunjukkan penggunaan aplikasi Qlue sebagai medium untuk mendapatkan aspirasi publik dan meresponnya daripada menggunakannya sebagai medium komunikasi satu arah dari pemerintah ke masyarakat.

Di sektor perbankan, dalam jurnal Strategi Branding Jakone Mobile Melalui Sinergi BUMD Taman Jajan Jakone Mobile Thamrin 10, teknologi dan aplikasi mobile dimanfaatkan untuk memberikan pelayanan yang lebih baik kepada konsumen sekaligus sebagai branding produk dan institusi. Bank DKI sebagai bank pemerintah daerah milik Pemerintah Provinsi Jakarta meluncurkan produk JakOne Mobile sebagai aplikasi mobile banking dan mobile wallet (Fauzia; Sujono, 2020). Fitur dari aplikasi tersebut menawarkan sistem pembayaran berbasis mobile application. 
Ipi Maryati Kuding, Irwansyah: Pemanfaatan Ragam Aplikasi Seluler Antikorupsi dalam Upaya Pencegahan Korupsi

Sedangkan Jurnal Open Government and e-Government membahas pentingnya penggunaan data set oleh masyarakat sebagai upaya mendorong transparansi. Penelitian yang dilakukan tersebut menghasilkan argumentasi tentang pentingnya prinsip-prinsip pemerintahan terbuka agar mengacu pada nilai publik. Data set yang diakses masyarakat harus terdiri dari data yang andal dan valid, bermanfaat, dan yang paling penting memungkinkan warga negara untuk melakukan sesuatu yang mereka anggap berharga dan penting (Harrison et al., 2011). Jika tidak, transparansi hanyalah janji kosong.

\section{Information and Communication Technologies (ICT) dalam Industri Komunikasi}

Information and Communication Technologies (ICT) atau dalam Bahasa Indonesia dikenal dengan Teknologi Informasi dan Komunikasi (TIK) adalah teknologi yang dapat memberikan layanan akses terhadap data dan informasi kepada penggunanya melalui sistem berbasis telekomunikasi. TIK tidak dapat dilepaskan dari kehadiran internet dan ponsel sebagai perangkat pendukung. Ponsel dideskripsikan sebagai perangkat media yang intim, personal, dan portabel, dan juga disebut sebagai 'layar keempat' setelah layar bioskop, televisi, dan komputer (Goggin, 2013). Martin Cooper, adalah orang yang berjasa dibalik kehadirannya. Cooper juga dikenal sebagai "bapak telepon genggam" setelah mengenalkan ponsel pertamanya tersebut (Harris \& Cooper, 2019). Empat puluh tahun setelah penemuan tersebut, kemudian para insinyur berhasil mengembangkan produkproduk baru ponsel yang memungkinkan aktivitas mobile (West, 2014). Itu sekelumit perjalanan ponsel sejak ditemukan.

Dalam perspektif industri komunikasi, perkembangan teknologi seluler dapat dilihat dari empat faktor, pertama, adanya jaringan data berkecepatan tinggi yang dapat mendukung pengguna untuk mengakses internet. Kedua, adanya pengembangan perangkat teknologi yang memiliki performa tinggi dengan harga yang kompetitif dengan beragam kapasitas penyimpanan dan processing. Ketiga, adanya marketplace untuk aplikasi yang mudah digunakan oleh pengguna dan mendukung adanya pengembangan industri aplikasi. Dan keempat, meningkatnya kebutuhan manusia untuk menggunakan aplikasi yang praktis. Penggunaan aplikasi mobile yang semakin meningkat, mendorong banyak perusahaan atau organisasi untuk membuat aplikasi yang lebih mudah diakses oleh pengguna (Tracy, 2012).

Seiring dengan perkembangan perangkat keras seluler yang semakin baik, juga mendorong tumbuhnya industri perangkat lunak. Fitur-fitur gawai pintar kini lebih bergantung pada perangkat lunak. Salah satu operating system (OS) yang sangat digemari saat ini adalah Android. Sistem operasi ondroid semakin populer, karena OS Android adalah sistem operasi berbasis Linux yang merupakan open source. Android dikembangkan oleh Open Handset Alliance yang dipimpin oleh Google dan perusahaan lain (Sharma \& Thakur, 2014). Pengguna ponsel dengan operating system Android dapat mengunduh beragam aplikasi pada Google playstore. Google playstore atau dikenal dengan playstore adalah toko onestop untuk ribuan aplikasi Android di pasar online yang didedikasikan untuk mempromosikan adopsi aplikasi seluler kompatibel dengan platform Android (Liu, $\mathrm{Au}, \&$ Choi, 2014). Playstore pada awalnya merupakan pasar untuk barang-barang 
elektronik, tetapi baru-baru ini diperluas hingga termasuk perangkat smartphone dan tablet (Djurup, 2013). Dalam perkembangannya, Android sebagai salah satu operating system maupun Google play yang menyediakan beragam aplikasi berbasis Android kian menarik perhatian pengguna ponsel. Dalam industri perangkat lunak, Android bahkan mengalahkan pendahulunya sesama OS, yaitu Blackberry yang diluncurkan pada 1999 dan iOS yang diperkenalkan pertama kali pada 2007 serta ponsel lainnya berbasis windows pada 2010.

Sedangkan, iOS adalah sistem operasi untuk iPhone yang diperkenalkan bersamaan dengan iPhone oleh Apple.Inc pada 2007 dan didesain serta didistribusi secara eksklusif oleh Apple dan aplikasi yang dikembangkan dalam lingkungan pendukungnya (Le, 2017). Jika aplikasi berbasis Android dapat diunduh pada Google Play store, maka aplikasi berbasi iOS dapat diunduh pada App store. OS Iphone pertama kali diperkenalkan oleh Steve Jobs pada Januari 2007 saat konferensi Macworld. Gagasan awalnya bermula dari Apple yang mengembangkan platform iOS bersamaan dengan iPhone pada tahun 2008 (Tracy, 2012). Perkembangan iOS kemudian semakin populer dan mengarah kepada era pembentukan aplikasi yang dijual di App store dan dapat digunakan pada iPhone atau iPad (Le, 2017).

Aplikasi seluler dikategorikan dalam dua jenis (Wong, 2012), yaitu aplikasi mobile dan aplikasi berbasis web. Aplikasi mobile terdiri atas aplikasi asli, yaitu aplikasi yang dibuat khusus untuk platform yang dirancang dan aplikasi hibrida yang menggabungkan fitur aplikasi asli dengan aplikasi berbasis web. Sedangkan, aplikasi berbasis web itu sendiri membutuhkan akses internet untuk dapat menggunakannya. Aplikasi adalah perangkat lunak yang dikembangkan dan diberi kode dengan sistem operasi tertentu. Pengguna harus mengunduhnya sebelum digunakan. Melalui aplikasi, pengguna masih dapat mengakses informasi jaringan yang ditautkan oleh aplikasi. Situs web seluler adalah versi seluler situs web internet. Pengguna dapat menggunakan browser yang sudah diinstal sebelumnya (mis., Safari untuk iPhone) untuk mengaksesnya. Tidak perlu mengunduh sebelum menggunakan.

Aplikasi juga merupakan program yang dirancang khusus untuk perangkat seluler seperti ponsel cerdas, tablet, dan perangkat yang dapat dikenakan. Dengan pertumbuhan eksplosif dari perangkat seluler, aplikasi menjadi hal biasa sejak Apple memperkenalkannya untuk iPhone (Ganapati, 2015). Pada Oktober 2007, perusahaan Apple juga mengumumkan bahwa developer dapat membuat aplikasi dalam iPhone (McWherter \& Gowell, 2012). Selain itu, interaksi antara inovasi teknologi dan inovasi sosial dipercaya dapat memecahkan masalah sosial dan ekonomi saat ini seperti isu perubahan iklim, penyakit kronis, dan ketidaksetaraan (Morrar \& Arman, 2017). Namun, dengan penekanan pada aspek keberlanjutan dan bahwa masyarakat luas harus mendapat manfaat dari transformasi industri tersebut. Industri 4.0 juga telah membuat semua hal terhubung dengan internet dan interkoneksi antara semua perangkat dan internet, yang dikenal dengan istilah Internet of Things (IoT). 
Ipi Maryati Kuding, Irwansyah: Pemanfaatan Ragam Aplikasi Seluler Antikorupsi dalam Upaya Pencegahan Korupsi

\section{Mobile Government Application}

Fenomena ini pada akhirnya memaksa dan mengubah cara pemerintah berkomunikasi kepada masyarakat, terutama dalam pelayanan publik. Pemerintah dengan segenap jajarannya kemudian berupaya beradaptasi hingga melahirkan teknologi Mobile Government (mGov). mGov mengembangkan sistem layanan dengan memanfaatkan jaringan terbuka yang bersifat virtual. Dalam konsep open government, mGov merupakan bagian dari e-Gov. Teknologi mGov juga mendorong sistem layanan pemerintah bertransformasi dari model tradisional menjadi berbasis teknologi dengan menawarkan kemudahan akses, ketersediaan, lebih dinamis, dan mampu meningkatkan partisipasi warga. Hal ini sangat membantu untuk memperkenalkan kebijakan pemerintah. Termasuk, mendekatkan isu antikorupsi kepada masyarakat. Karenanya, pemanfaatan aplikasi seluler sebagai sarana mensosialisasikan, mengedukasi dan mengkampanyekan nilai antikorupsi dapat dilakukan dengan berpedoman pada nilai kemanfaatan bagi masyarakat. Disisi lain, pertumbuhan perangkat dan aplikasi seluler juga menghadirkan peluang baru di sektor publik. Di Amerika Serikat ada dua jenis aplikasi pemerintah (Ganapati, 2015), yaitu pertama, aplikasi yang berfokus pada perusahaan terutama untuk penggunaan internal dalam organisasi publik. Mereka hanya dapat diakses oleh karyawan dan beroperasi di dalam firewall yang aman yang dibuat oleh organisasi. Kedua, aplikasi yang berorientasi pada warga negara ditujukan untuk penggunaan eksternal. Mereka dapat diakses oleh siapa saja yang ingin menggunakan layanan pemerintah.

Sementara, m-Government (OECD/International Telecommunication Union, 2011) dapat dikelompokkan menjadi empat kategori berdasarkan tujuan layanan tersebut diberikan, yaitu layanan pemerintah untuk publik (G2C), pemerintah dengan bisnis (G2B), pemerintah dengan pemerintah (G2G), dan pemerintah dengan karyawan (G2E). Dalam konteks m-government, penggunaan aplikasi seluler akan memberikan manfaat, seperti meningkatkan transparansi dan akuntabilitas, menyediakan akses ke layanan elektronik, meningkatkan interaksi dengan warga negara, dan menjadi saluran baru untuk menyampaikan kontribusi, tuntutan, dan keluhan. Peluang itu yang dimanfaatkan oleh KPK dalam upaya pencegahan korupsi dengan membuka data dan informasi serta memfasilitasi keluhan terkait layanan publik. Aplikasi seluler antikorupsi KPK adalah termasuk $\mathrm{G} 2 \mathrm{C}$, yaitu sebagai layanan yang memediasi pemerintah dengan publik.

\section{Uses and Gratification Theory}

Untuk menjelaskan perilaku konsumsi informasi oleh individu berdasarkan teori kegunaan dan gratifikasi (uses and gratification theory) ada tiga perilaku penggunaan media sebagai sumber informasi, yaitu mengkonsumsi, berpartisipasi, dan memproduksi. Individu pengguna media saat ini dengan teknologi yang lebih baru, memiliki lebih banyak pilihan media, yang sebelumnya hanya dibagikan dengan individu lain sebagai media massa. Tidak seperti media massa tradisional, media baru seperti internet memberikan karakteristik selektivitas yang memungkinkan individu menyesuaikan pesan dengan kebutuhan mereka (Ruggiero, 2017). 
Perilaku mengkonsumsi merujuk pada aktivitas individu yang hanya menonton, membaca, atau melihat informasi dan hiburan yang disajikan sebuah situs. Perilaku yang berpartisipasi adalah termasuk interaksi antara pengguna ke pengguna lainnya dan interaksi pengguna ke konten, seperti misalnya memberikan penilaian, menambah daftar putar, berbagi, atau memberikan komentar. Perilaku berpartisipasi ini biasanya ditunjukkan terutama untuk interaksi dan koneksi sosial serta pengembangan komunitas virtual. Sedangkan, perilaku memproduksi mengacu pada penciptaan dan publikasi karya pribadi seseorang seperti teks, gambar, audio, dan video, terutama berdasarkan pada ekspresi diri atau motivasi aktualisasi diri. Teori ini memandang bahwa penggunaan media dari perspektif audiens adalah motif penggunaan media oleh audiens untuk mendapatkan kepuasan. Yang mengasumsikan bahwa orang menggunakan sebuah media untuk memenuhi kebutuhan yang mendasarinya.

Penemuan dan kemajuan teknologi web 4.0 telah membawa perubahan signifikan dalam interaksi dan komunikasi antar manusia. Teknologi telah mengubah dari kehidupan nyata ke kehidupan virtual. Menggeser orang biasa ke ruang-ruang ini (Rachna, Khajuria, $\alpha, \&$ Khajuria $\sigma$, 2017). Tingginya kecenderungan terhadap pemilihan internet dibandingkan media tradisional dalam hal pemenuhan kebutuhan mengukuhkan teori kegunaan dan gratifikasi yang menjelaskan mengapa khalayak lebih memilih menggunakan media tertentu (Mehrad \& Tajer, 2016) dari pada media lainnya sebagai sumber untuk memenuhi kebutuhan informasi, data maupun penyampaian aspirasi.

\section{Metode Penelitian}

Penelitian ini menggunakan pendekatan kualitatif dengan paradigma konstruktivis. Penelitian kualitatif membutuhkan sebuah deskripsi atau narasi tentang sebuah tindakan spesifik yang menghubungkan antara konsep dengan data (Newman, 2014). Sedangkan, paradigma konstruktivis adalah asumsi yang dikembangkan oleh individu melalui pemaknaan subjektif atas pengalaman personal individu tersebut (Creswell \& Poth, 2017).

Desain penelitiannya adalah studi kasus. Kasus-kasus yang diangkat tidak hanya tentang individu tetapi juga bisa meliputi kelompok, organisasi, isu, proses, konsep dan lainnya (Daymon \& Holloway, 2010). Penelitian ini menetapkan unit analisisnya adalah pengguna aplikasi seluler KPK serta tim pengembang/pengelola aplikasi-aplikasi seluler KPK tersebut. Sesuai dengan unit analisis, subyek penelitian adalah pengalaman dalam menggunakan aplikasi seluler antikorupsi sebagai media komunikasi, edukasi dan menampung keluhan layanan publik. Subyek yang menjadi informan penelitian ini adalah masyarakat pengguna aplikasi dan pegawai KPK sebagai pengelola aplikasi.

Sedangkan, teknik pengumpulan data pada penelitian ini adalah studi literatur atau document research terhadap penelitian-penelitian sejenis sebelumnya serta dokumen dan informasi yang dimiliki oleh tim pengembang dan pengelola aplikasi seluler antikorupsi milik KPK. Data tersebut kemudian disatukan dengan hasil wawancara terhadap tiga informan pengguna aplikasi yang terdiri dari aktivis pegiat antikorupsi, guru dan orang tua murid, serta satu orang pegawai KPK sebagai 
Ipi Maryati Kuding, Irwansyah: Pemanfaatan Ragam Aplikasi Seluler Antikorupsi dalam Upaya Pencegahan Korupsi

tim pengelola aplikasi. Pengolahan data penelitian dilakukan dengan koding terbuka, axial dan selektif untuk kemudian disatukan dan disajikan dalam bentuk uraian atau gambaran yang secara keseluruhan dapat menjelaskan permasalahan. Selanjutnya, uraian tersebut menjadi bahan pertimbangan penyusunan kesimpulan yang menjawab rumusan masalah.

\section{Hasil Penemuan dan Diskusi}

Tahun 2016 KPK meluncurkan sebuah platform digital bernama JAGA, yaitu sebuah aplikasi berbasis mobile yang diinisiasi oleh KPK bekerja sama dengan kementerian dan lembaga. Platform tersebut menyajikan data seputar informasi pelayanan publik yang dimiliki oleh kementerian dan lembaga tersebut. Aplikasi JAGA dapat diunduh baik melalui Google play store atau di App store. Di tahap awal JAGA meluncurkan tiga menu utama, yaitu Pendidikan, Dana Desa dan Fasillitas Kesehatan. Melalui ketiga menu tersebut, pengguna dapat mengakses informasi dan data tentang pelayanan publik dari ketiga menu tersebut.

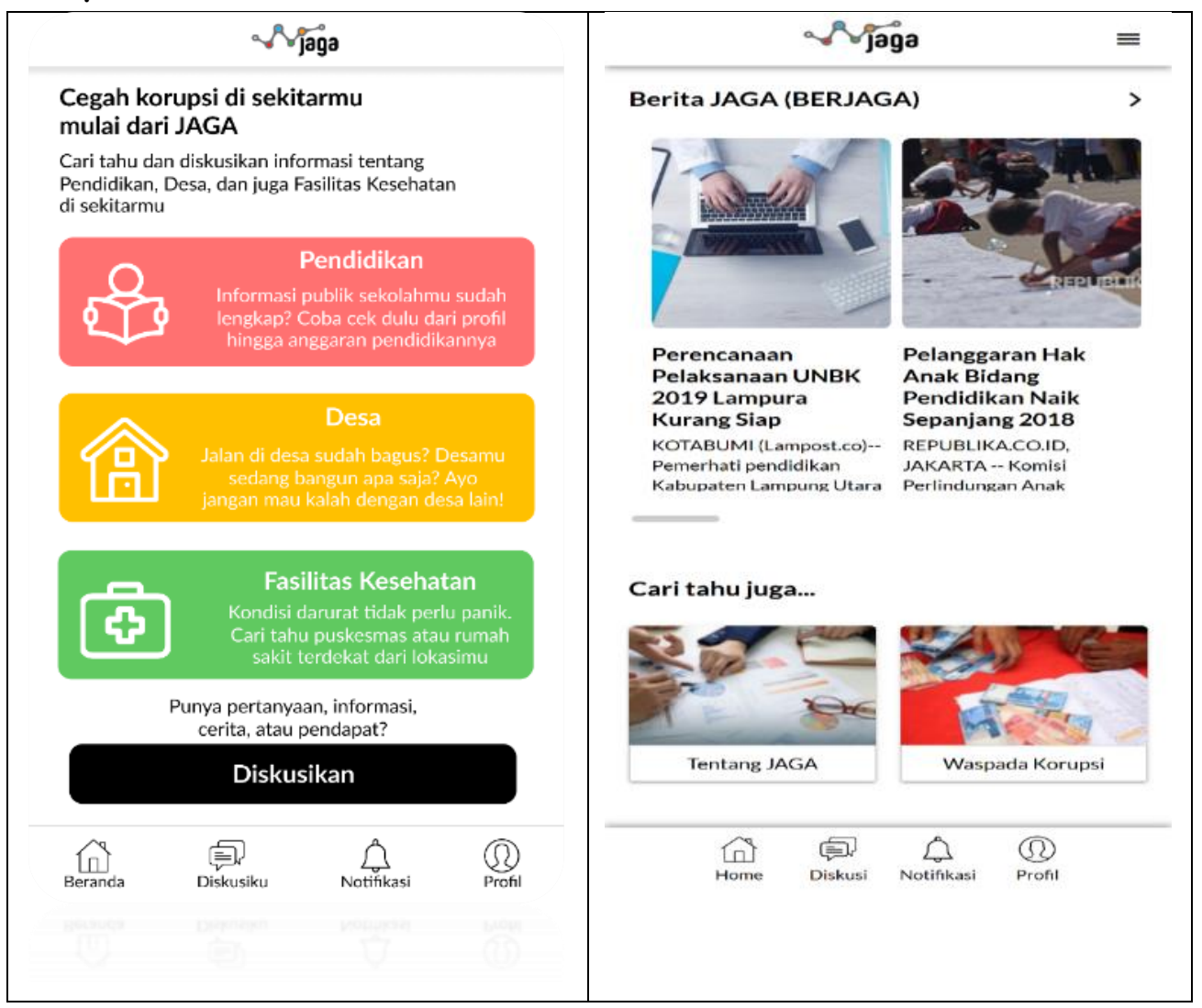

Gambar 1: Menu pada Platform JAGA

Sejak diluncurkan pada tahun 2016 sampai dengan saat ini, JAGA telah mengumpulkan lebih dari 400.000 profil sekolah dan informasi lainnya di bidang pendidikan. Selain itu, juga terdapat 13.000 profil rumah sakit dan puskesmas, serta 74.000 profil desa di seluruh Indonesia. Tahun 2019 tiga menu pada JAGA ditambah dengan dua menu lainnya, yaitu anggaran dan perizinan. Terakhir pada 
Mei 2020, KPK meluncurkan menu Bansos Covid-19 sebagai fitur terbaru. Jika 5 fitur sebelumnya menyajikan informasi tentang layanan publik dan akses informasi tentang anggaran pendapatan dan belanja pada pemerintah daerah, fitur JAGA Bansos Covid-19 diluncurkan untuk merespon keluhan masyarakat terkait pendistribusian bantuan sosial (bansos) di masa pandemi Corona Virus Disease 2019 (Covid-19).

Selain menyajikan data dan informasi tentang keenam menu utama, platform tersebut juga menyediakan fitur diskusi sebagai bentuk interaktivitas. Selain itu, juga terdapat fitur lainnya yaitu berJAGA (berita JAGA), cerita sukses, tentang JAGA, dan waspada korupsi. Dari sisi tata kelola pemerintahan, platform JAGA diluncurkan dengan tujuan untuk mendukung implementasi open government dengan mendorong transparansi atau keterbukaan data (open data) oleh kementerian, lembaga pemerintah maupun pemerintah daerah. Dengan membuka data kepada publik, mendorong pemerintah baik di tingkat pusat maupun daerah untuk terus melakukan evaluasi dan perbaikan pada sistem kelembagaan dan tata kelola pelayanan publik. Interaktivitas yang ditawarkan platform JAGA, diharapkan dapat mendorong partisipasi dan terbangunnya kolaborasi antara pemerintah sebagai penyedia layanan publik dengan masyarakat sebagai pengguna layanan publik, termasuk pelibatan komunitas.

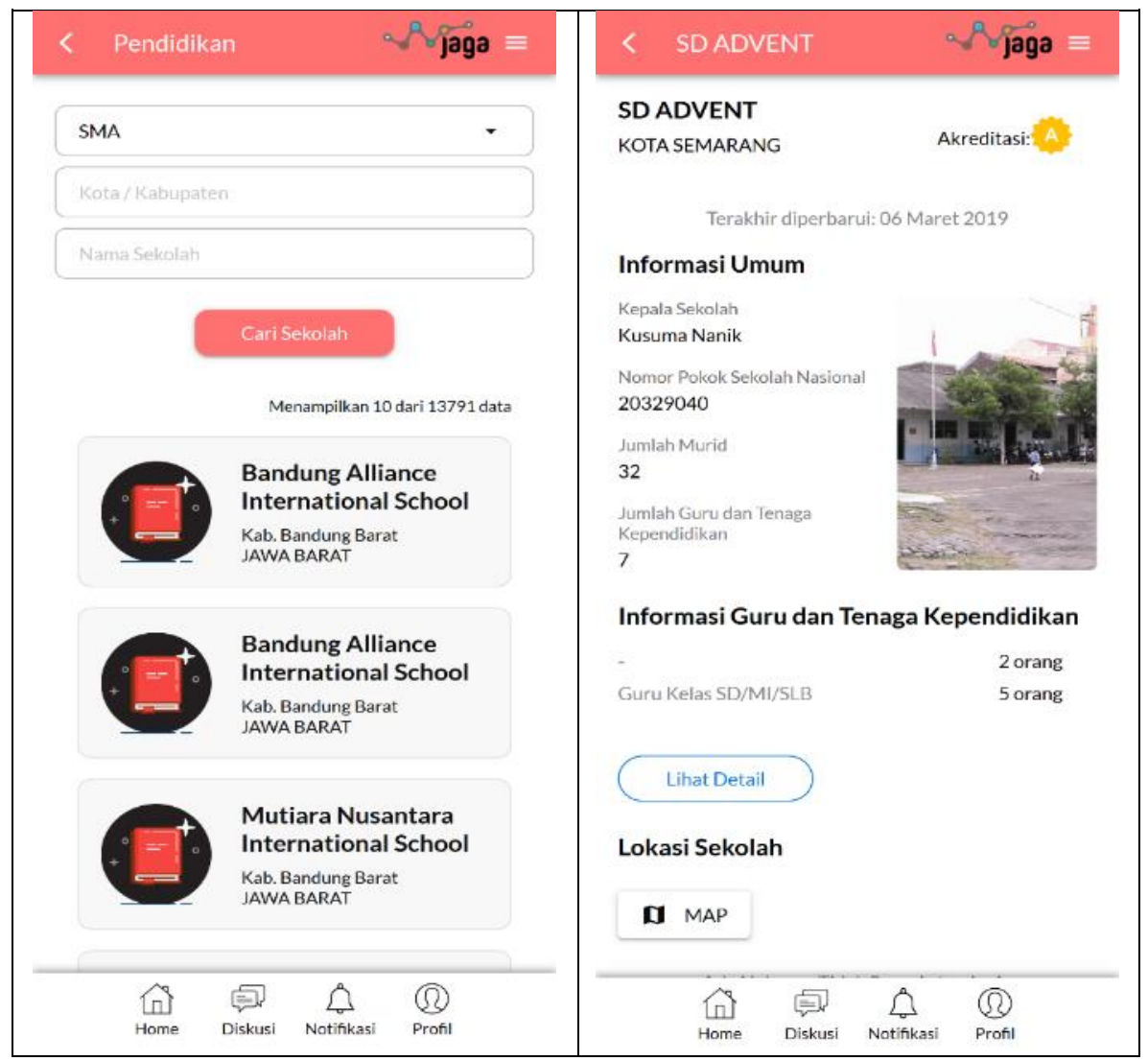

Gambar 2: Fitur Menu Fasilitas Pendidikan JAGA 
Ipi Maryati Kuding, Irwansyah: Pemanfaatan Ragam Aplikasi Seluler Antikorupsi dalam Upaya Pencegahan Korupsi

Pada menu fokus sektor pendidikan seperti gambar di atas misalnya, pengguna dapat mengakses informasi tentang pendidikan anak usia dini (PAUD) dan pendidikan dasar dan menengah (Dikdasmen) yang meliputi informasi dan data tentang profil sekolah, dana bantuan operasional sekolah (BOS), Program Indonesia Pintar (PIP), penerimaan peserta didik baru, dan sebagainya. Selain itu, ada juga informasi dan data tentang pendidikan tinggi yang meliputi informasi tentang profil Perguruan Tinggi, BPPTN, BKT, dan UKT. Sedangkan, pada menu fokus sektor kesehatan, pengguna dapat mengakses informasi tentang profil puskesmas, rumah sakit, klinik, BPJS, dan sebagainya termasuk fasilitas, sarana dan prasarana juga tenaga medis yang dimiliki masing-masing fasilitas kesehatan tersebut. Pada menu fokus sektor dana desa, pengguna dapat mengakses informasi dan data tentang anggaran desa, pembangunan desa hingga partisipasi masyarakat desa. Fitur diskusi dan berbagi cerita juga tersedia pada menu dana desa seperti pada menu kesehatan dan pendidikan.

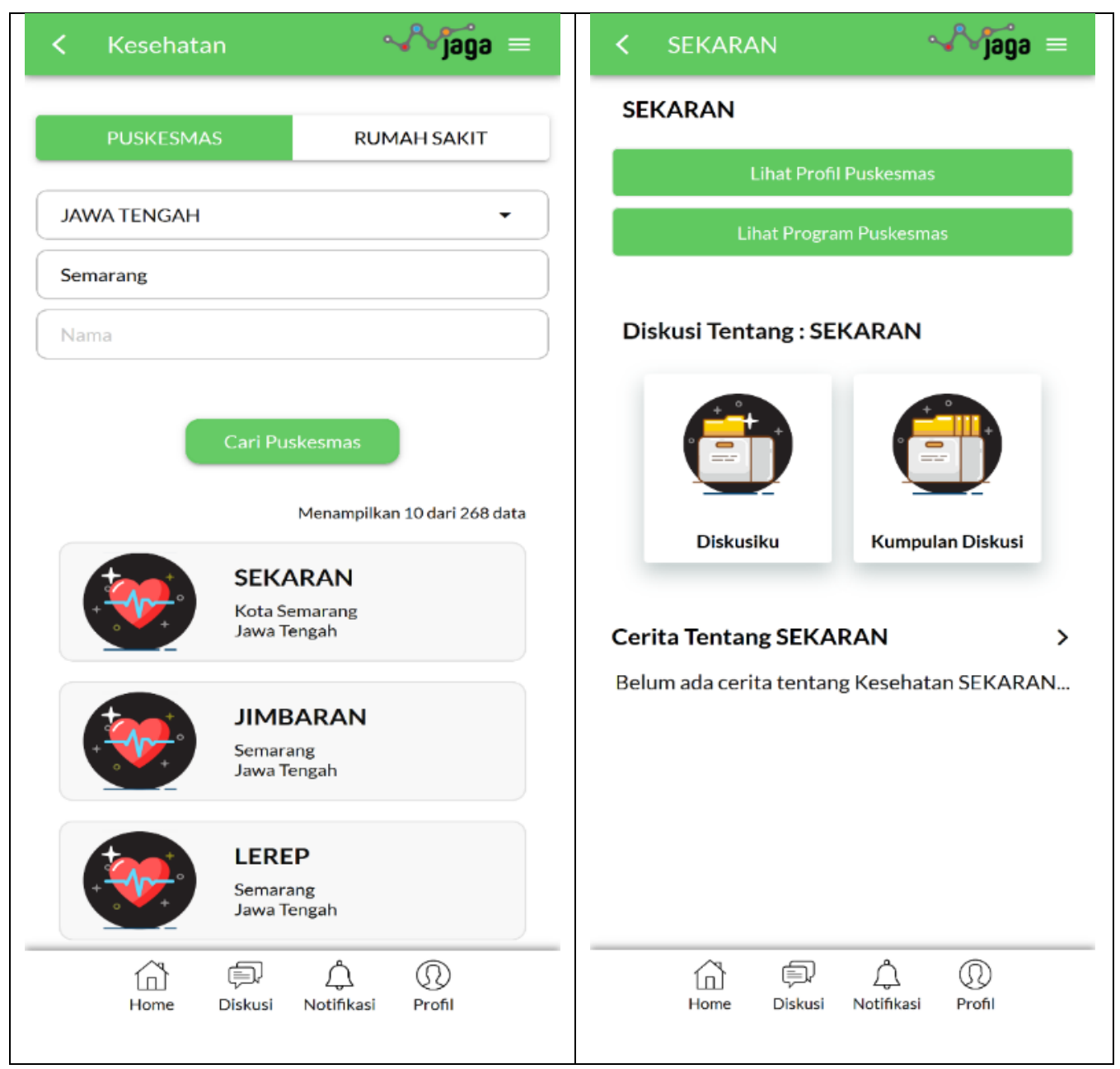

Gambar 3: Fitur Menu Fasilitas Kesehatan JAGA 
Bagaimana jika data dan informasi yang disajikan tidak sesuai profil asli di lapangan? Jawabannya ada pada fitur diskusi dan berbagi cerita yang juga disediakan dalam platform tersebut. Fitur ini memfasilitasi interaktivitas antara pengguna dengan tim pengelola aplikasi atau platform yang bertugas sebagai narasumber yang memoderasi percakapan dan komunikasi dalam fitur tersebut. Masyarakat atau pengguna layanan publik yang mendapatkan kenyataan tidak sesuai dengan informasi dan data yang disajikan dalam aplikasi platform JAGA, dapat berbagi informasi dalam fitur ini. Tim pengelola akan merespon dan jika diperlukan meneruskan kepada instansi, kementerian atau lembaga pemerintah terkait. Informasi dari masyarakat menjadi masukan dan koreksi bagi pemerintah yang mengelola layanan publik terkait untuk membuat perbaikan atau mengambil langkah-langkah lainnya yang diperlukan.

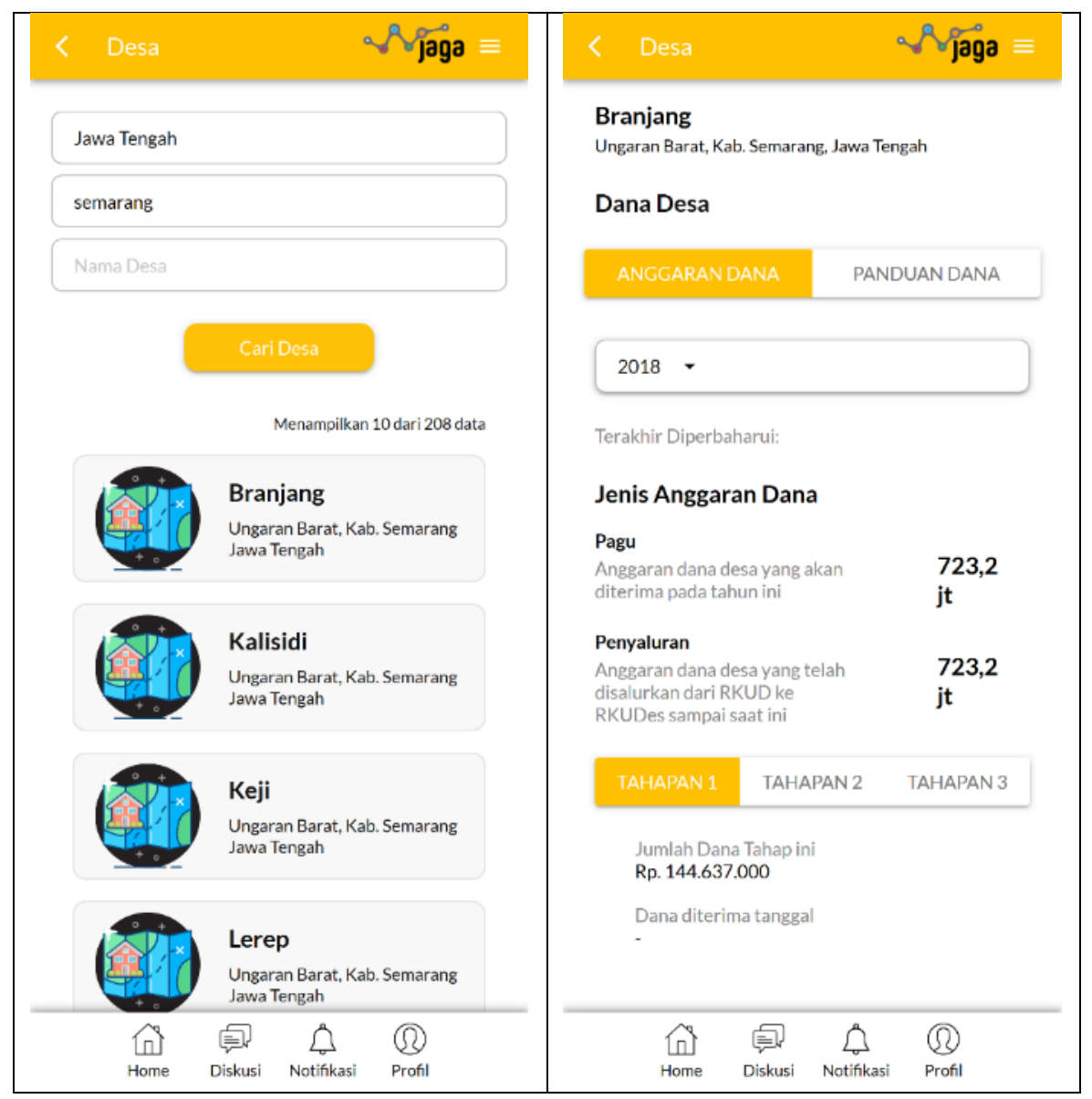

Gambar 4: Fitur Menu Dana Desa JAGA

Selain platform JAGA yang dapat diunduh di Appstore, KPK juga mempunyai beberapa aplikasi berbasis seluler lainnya yang dapat diunduh pada dua toko online berbasis Android dan iOS, yaitu: Gratifikasi Online (GOL) dan Gratis2Go. Kedua aplikasi digital ini memberikan kemudahan bagi masyarakat. Aplikasi GOL membantu masyarakat khususnya pegawai negeri dan penyelenggara negara dalam menyampaikan pelaporan penerimaan gratifikasi secara online, 
Ipi Maryati Kuding, Irwansyah: Pemanfaatan Ragam Aplikasi Seluler Antikorupsi dalam Upaya Pencegahan Korupsi

sehingga pegawai dan penyelenggara negara tersebut tidak harus datang secara langsung ke gedung KPK. Kehadiran aplikasi GOL menjadi alternatif solusi pelaporan gratifikasi secara online tanpa terikat ruang dan waktu. Sedangkan aplikasi Gratis2Go merupakan medium pembelajaran online untuk membantu masyarakat memahami tentang gratifikasi. Dalam menu modulnya terdapat beberapa topik pembelajaran, yaitu pengertian gratifikasi, siapa saja yang dilarang menerima gratifikasi, bentuk gratifikasi dalam kehidupan sehari-hari, dan bahaya gratifikasi. Kedua aplikasi gratifikasi ini seperti yang diungkapkan Ganapati berorientasi pada warga negara yang ditujukan untuk penggunaan eksternal. Warga dapat mengaksesnya kapan dan di mana saja untuk terhubung dengan layanan tersebut. Inilah keunggulan dan kemudahan selain juga biaya yang murah dan menghemat waktu yang dapat ditawarkan oleh aplikasi berbasis online dalam penyediaan layanan, karena pengguna tidak harus datang langsung ke Gedung KPK.

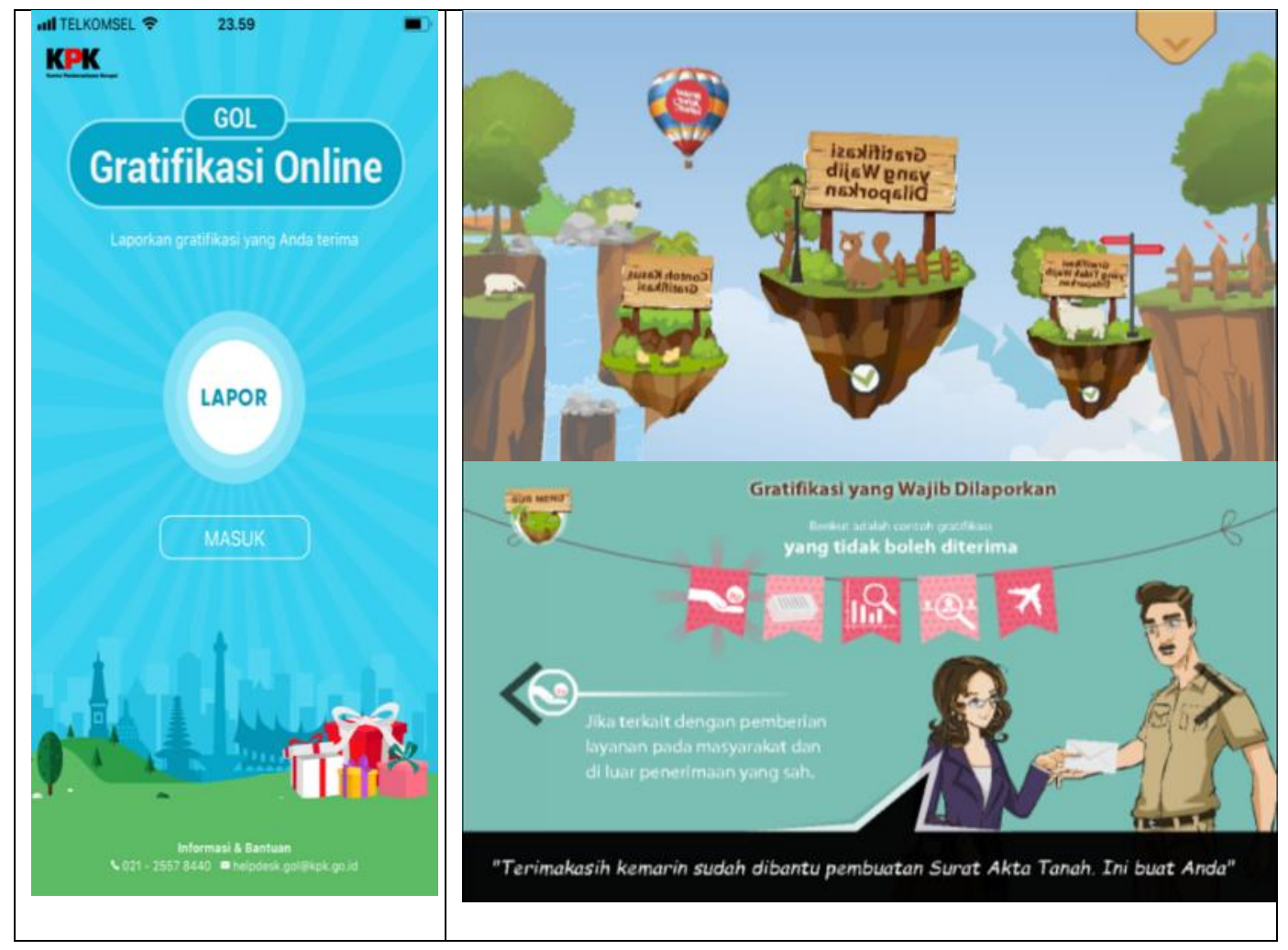

Gambar 5: Aplikasi Pelaporan Gratifikasi Online dan e-Learning Gratifikasi

Konsep aplikasi selular ini secara praktis telah memfasilitasi terbangunnya komunikasi dua arah yang interaktif. Melalui komunikasi interaktif ini diharapkan dapat mendorong praktik open government, yang membuka ruang partisipasi dan kolaborasi antara warga yang tidak hanya bertindak sebagai pengguna data dan informasi, tetapi juga sebagai warga yang memberikan kontribusi untuk perbaikan layanan publik pemerintah. Berdasarkan data dan informasi yang diperoleh selama penelitian, teknologi ini telah membawa perubahan bagi lembaga KPK khususnya personel yang menjadi tim pengembang dan pengelola aplikasi secara langsung, 
terutama terkait proses permintaan dan akuisisi data dari berbagai kementerian, lembaga dan pemerintah daerah dalam upaya penyediaan dan pengkinian data yang relevan. Kesediaan untuk memberikan data yang dibutuhkan sekali lagi merupakan bagian dari tujuan dihadirkannya platform ini, yaitu mendorong transparansi dan akuntabilitas pelayanan publik oleh pemerintah dalam hal ini kementerian, lembaga dan pemerintah daerah penyedia layanan publik. Namun, kenyataannya tim pengelola masih perlu melakukan pendekatan khusus untuk memperoleh data yang dibutuhkan.

Sehingga, hal tersebut berdampak langsung pada aspek keterandalan data. Tim pengembang mengakui masih terdapat kelemahan pada data yang disajikan. Kadang disebabkan karena hal teknis terkait proses untuk mengakuisisi data dan informasi yang dibutuhkan karena berada pada kementerian/lembaga yang terpisah, sehingga data belum dapat disajikan. Selain itu, beberapa kendala lainnya yang ditemukan tim di lapangan adalah data yang dibutuhkan terkadang masih belum tersedia pada kementerian dan lembaga terkait atau persoalan teknis terkait pengelolaan data di mana data dan informasi yang dibutuhkan belum terpusat di satu unit kerja. Di sisi lain, teknologi informasi dan komunikasi ini juga menuntut kesiapan personel sebagai tim pengelola untuk dapat merespon kebutuhan dan minat publik akan informasi dan data yang dibutuhkan dan bermanfaat untuk mereka. Dari kegiatan wawancara yang dilakukan terhadap tiga aktivis dan pegiat antikorupsi, guru dan orang tua murid ditemukan bahwa mayoritas menilai ragam data yang disajikan cukup lengkap. Namun, untuk sebagian pihak mengalami kesulitan memahami fitur dan konten keseluruhan JAGA. Hal ini berkontribusi pada kemampuan pengguna untuk dapat memanfaatkan informasi dan data yang disajikan sebagai bahan membuat analisis atau mengolah data tersebut lebih lanjut.

Selain itu, beberapa informasi dan data yang disajikan dinilai masih sedikit dan belum lengkap. Beberapa data yang masih perlu dilengkapi misalnya, antara lain seperti informasi tentang sarana yang dibangun desa pada menu desa, baik terkait aktor pembangunan maupun terkait dana. Demikian juga informasi tentang jalan desa, pengguna merasa tidak mendapatkan informasi yang cukup tentang jalan provinsi, kabupaten, atau desa. Termasuk informasi panjang jalan dan pemanfaatan dari sisi ekonomis. Informasi lainnya yang juga dinilai penting pada menu desa, adalah informasi APBDesa. Tidak hanya dari sisi kelengkapan data, pengguna juga berharap tampilan lebih menarik. Penyajian data dalam bentuk statistik dinilai lebih informatif dan mudah dipahami. Selain itu, beberapa ikon dan tombol kurang dipahami kegunaannya oleh pengguna. Meski demikian, seluruh informan yang diwawancarai menyatakan aplikasi JAGA penting, tapi sebagian tidak berencana untuk mengunduh aplikasi tersebut pada gawainya. Salah satunya disebabkan tidak familiarnya dengan beberapa istilah yang digunakan. Beberapa fitur pada halaman utama misalnya, informan bingung pada fitur "Diskusikan" dan "Ketahui Hak Anda". Sehingga, secara keseluruhan masih kurang baik dalam memahami fungsifungsi tombol dan tampilan aplikasi.

Temuan lainnya adalah perlunya untuk mengubah dan membangun tingkat kebutuhan pengguna terhadap data. Literasi media yang cukup tinggi dari pengguna dan kemudahan akses kepada situs terkait, membuat pengguna tidak menggunakan aplikasi JAGA sebagai pilihan pertama dalam mengakses data dan informasi. 
Ipi Maryati Kuding, Irwansyah: Pemanfaatan Ragam Aplikasi Seluler Antikorupsi dalam Upaya Pencegahan Korupsi

Mayoritas pengguna akan memilih metode lain untuk mencari informasi tentang pelayanan publik, seperti melalui mesin pencarian Google, bertanya atau diskusi dengan teman, langsung mengunjungi situs instansi terkait atau menghubungi instansi terkait secara langsung melalui saluran telepon. Selain itu, didapatkan temuan lainnya terkait tujuan platform JAGA, yaitu untuk mendorong perbaikan sistem dengan mendorong keterbukaan data telah ditindaklanjuti oleh beberapa instansi terkait. Salah satunya pada sektor pendidikan. Dari informan pengelola aplikasi diketahui bahwa Kepala Dinas Pendidikan Kabupaten Bangka telah mengeluarkan surat yang menginstruksikan seluruh sekolah untuk melakukan pengkinian data pendidikan dan laporan penggunaan dana BOS dengan benar. Selain karena dimonitor oleh JAGA, juga tumbuhnya kesadaran pentingnya transparansi dan pelibatan partisipasi publik untuk menutup ruang-ruang gelap yang menjadi celah potensi korupsi. Keberhasilan lainnya di bidang pendidikan adalah JAGA berhasil mendorong dilakukannya akselerasi perbaikan aplikasi database madrasah Kementerian Agama (EMIS) dan melakukan pengkinian data secara rutin. Pada saat yang sama, semakin dikenalnya platform JAGA, mendorong para pihak penyedia data pelayanan publik semakin aktif untuk melengkapi data dan informasi yang dibutuhkan. Salah satunya perbaikan data guru di seluruh Indonesia kini datanya sudah dibuka di platform JAGA.

Sedangkan terkait transparansi data, JAGA telah mendorong transparansi dan dibukanya data yang sebelumnya sulit untuk diakses. Salah satunya pada sektor kesehatan, kini data kepesertaan, kapitasi, dan data puskesmas dari BPJS dapat diakses melalui platform ini. Di sektor pengelolaan dana desa, JAGA mendorong pemerintah desa untuk melaporkan penggunaan dana desa secara akuntabel. Pada sisi pengguna atau masyarakat secara umum, kehadiran platform JAGA mendorong pemberdayaan masyarakat. Salah satunya masyarakat di Pandeglang akhirnya memperoleh hak kartu Indonesia pintar yang sebelumnya disalahgunakan oleh kepala sekolah. Masyarakat awalnya tidak mengetahui bahwa mereka berhak menerima bantuan tersebut. Informasi tersebut awalnya diketahui dari platform JAGA yang kemudian mendorong masyarakat untuk mempertanyakan hak mereka. Keterbukaan informasi dan data lainnya yang disajikan platform JAGA adalah hak ibu hamil untuk mendapatkan vitamin untuk menjaga kesehatan selama kehamilannya. Informasi tersebut baru diketahui setelah masyarakat membaca panduan JKN yang diunggah di platform JAGA. Penyediaan data terkait pengelolaan dana desa di platform JAGA juga telah meningkatkan pemahaman warga tentang dana desa yang kemudian mendorong peningkatan partisipasi masyarakat dan perempuan dalam mengawal dana desa.

Selanjutnya, terkait aplikasi gratifikasi ditemukan bahwa terdapat kecenderungan wajib lapor mulai berpindah memanfaatkan aplikasi tersebut untuk melaporkan gratifikasi. Tren penggunaan aplikasi GOL menunjukkan peningkatan. Sejak diluncurkan pada Desember 2017, tercatat total pelaporan sepanjang tahun 2018 berjumlah 509 laporan. Sedangkan, data pelaporan periode Januari hingga 30 Juni 2020 tercatat 784 laporan atau sekitar 73\% yang disampaikan melalui GOL dari total 1.082 laporan yang masuk. Di urutan ke dua pelaporan terbanyak disampaikan melalui e-mail sebesar $18 \%$. 


\section{Simpulan}

Semangat pemerintah untuk menjadi open government dengan mengimplementasikan e-Gov harus didukung, termasuk mengembangkan aplikasi mGov untuk meningkatkan layanan kepada masyarakat. KPK dalam upaya pencegahan korupsi telah mendorong implementasi praktik open government ini dengan mendorong open data. Salah satunya dilakukan dengan membuat aplikasi berbasis selular platform JAGA. Melalui platform ini, pemerintah melalui kementerian, lembaga dan pemerintah daerah yang memiliki kewajiban menyediakan pelayanan publik didorong untuk membuka data dan informasi tentang pelayanan publiknya kepada masyarakat. Sejak diluncurkan pada 2016 hingga saat ini, platform JAGA telah membuka ruang partisipasi publik dalam melakukan pengawasan terhadap jalannya pelayanan publik oleh pemeritahan khususnya terkait penyediaan informasi dan data pada sektor pendidikan, kesehatan, pengelolaan dana desa, anggaran, dan perizinan. Keterbukaan dipercaya akan menutup celah dan potensi korupsi. Ditambah dengan open data pemerintah akan didorong untuk terus melakukan perbaikan dalam menjalankan tugas sebagai badan publik yang menyediakan layanan publik. Ruang partisipasi yang difasilitasi melalui platform JAGA membuka kesempatan bagi masyarakat untuk memberikan masukan yang menjadi dorongan bagi pemerintah untuk terus berbenah. Di sisi lain, pemerintah yang mengetahui bahwa kinerjanya terus diawasi oleh masyarakat tidak memiliki peluang untuk menyembunyikan informasi dari masyarakat.

Temuan dalam penelitian juga mengindikasikan respon positif pengguna aplikasi terhadap aplikasi-aplikasi seluler berbasis android dan iOS yang diluncurkan oleh KPK. Dari sisi pengguna, aplikasi seluler antikorupsi mampu memenuhi kebutuhan khususnya kemudahan dalam akses yang tidak terikat ruang dan waktu. Hal ini ditandai salah satunya dengan tren peningkatan pemanfaatan aplikasi GOL sebagai medium pelaporan gratifikasi dibandingkan medium lainnya. Sedangkan, dari sisi penyedia layanan publik kehadiran platform JAGA telah mendorong badan publik untuk melengkapi dan memperbaiki kualitas data dan informasi layanan publik. Terbukanya akses publik kepada data, akhirnya mendorong badan publik untuk terus berbenah memperbaiki tata kelola data dan secara berkala melakukan pengkinian data. Pada implementasinya platform JAGA juga telah berhasil mendorong perbaikan sistem dengan mendorong keterbukaan data, meningkatkan literasi masyarakat tentang hak masyarakat untuk menerima dan mengakses layanan publik hingga mendorong pemberdayaan masyarakat. Sedangkan, e-learning dan gratifikasi online (GOL) merupakan aplikasi yang diluncurkan KPK sebagai bagian dari proses edukasi publik tentang transparansi dan akuntabilitas penyelenggara negara. Di era teknologi informasi dan komunikasi ini penggunaan gawai pintar dan akses internet yang sangat mudah membuat KPK harus menyesuaikan diri dalam membangun ruang partisipasi dan kolaborasi dengan segenap mitra pemangku kepentingan, tidak hanya kepada penyelenggara negara. Karenanya, pemanfaatan teknologi aplikasi selular sangat tepat dilakukan untuk dapat mengedukasi publik dengan jangkauan yang lebih luas. Namun demikian, masih banyak kelemahan dalam aplikasi-aplikasi tersebut dan dibutuhkan pengembangan lebih lanjut. Salah satunya terkait tampilan dan 
Ipi Maryati Kuding, Irwansyah: Pemanfaatan Ragam Aplikasi Seluler Antikorupsi dalam Upaya Pencegahan Korupsi

visualisasi data, nilai manfaat konten, keterandalan data dan bagaimana memanfaatkan konten tersebut untuk pencegahan korupsi. Bagi KPK sebagai pemilik aplikasi, sangat penting untuk memastikan nilai manfaat yang dapat dirasakan oleh masyarakat dengan hadirnya aplikasi-aplikasi selular tersebut.

Merujuk hasil penelitian di atas, tulisan ini merekomendasikan perlunya peningkatan literasi digital kepada masyarakat untuk memanfaatkan data dan informasi demi mendorong transparansi dalam konteks upaya pencegahan korupsi. Secara khusus tulisan ini juga merekomendasikan kepada pemerintah agar lebih responsif dalam menyediakan data demi mengoptimalkan layanan berbasis aplikasi seluler. Perangkat seluler telah menawarkan peluang tambahan bagi kementerian, lembaga dan pemerintah daerah untuk meningkatkan pelayanan publik. Juga perlu diperhatikan kelayakan struktur data standar di seluruh kementerian, lembaga dan pemerintahan daerah agar badan publik yang berbeda tetap dapat menyediakan data secara konsisten. Dan, bagi tim pengelola perlu mempertimbangkan untuk melakukan digital marketing untuk lebih mengenalkan JAGA dan fitur-fitur lainnya yang dibutuhkan pembacanya.

\section{Ucapan Terima Kasih}

Ucapan terima kasih dan penghargaan diberikan kepada editor dan tim Jurnal Komunikasi Universitas Tarumanagara yang telah menelaah dan mereview artikel ini hingga dapat diterbitkan pada Jurnal Komunikasi.

\section{Daftar Pustaka}

Creswell, J. W., \& Poth, C. N. (2017). Qualitative Inquiry and Research Design (International Student Edition): Choosing Among Five Approaches. SAGE Publications. Retrieved

from https://books.google.co.id/books?id=UgFIMQAACAAJ.

Daymon, C., \& Holloway, I. (2010). Qualitative research methods in public relations and marketing communications. Routledge.

Djurup, R. (2013). Android Mobile Computing Using Samsung Tablets and Smartphones Running Android 2.3 - Kindle version. Rebidu. Retrieved from https://books.google.co.id/books?id=m3Cz8-jrXtEC

Fauzia; Sujono, F. K. (2020). Strategi Branding Jakone Mobile Melalui Sinergi BUMD Taman Jajan Jakone Mobile Thamrin 10. https://doi.org/http://dx.doi.org/10.24912/jk.v12i2.6726

Ganapati, S. (2015). Using Mobile Apps in Government, 1-53.

Goggin, G. (2013). The evolution of Australian mobile screens: New technology, new formats, new business models. Studies in Australasian Cinema, 6(3), 263-277. https://doi.org/10.1386/sac.6.3.263_1

Harris, A., \& Cooper, M. (2019). Mobile phones: Impacts, challenges, and predictions. Human Behavior and Emerging Technologies, 1(1), 15-17. https://doi.org/10.1002/hbe2.112 
Harrison, T. M., Guerrero, S., Burke, G. B., Cook, M., Cresswell, A., Helbig, N., ... Pardo, T. (2011). Open government and e-government, (May 2014), 245. https://doi.org/10.1145/2037556.2037597

Le, T. (2017). iOS Development with Swift programming language iOS Development with Swift programming language.

Liu, C. Z., Au, Y. A., \& Choi, H. S. (2014). Effects of Freemium Strategy in the Mobile App Market: An Empirical Study of Google Play. Journal of Management Information Systems, 31(3), 326-354. https://doi.org/10.1080/07421222.2014.995564

Manara, M. U. (2016). Normalisasi Korupsi : Tinjauan Psikologi. Improving Moral Integrity Based on Family, (October).

McWherter, J., \& Gowell, S. (2012). Professional Mobile Application Development, $432 . \quad$ Retrieved from https://books.google.com/books?id=S7CIlnNkg8UC\&pgis $=1$

Mehrad, J., \& Tajer, P. (2016). Uses and gratification theory in connection with knowledge and information science: A proposed conceptual model. International Journal of Information Science and Management, 14(2), 114.

Morrar, R., \& Arman, H. (2017). The Fourth Industrial Revolution (Industry 4.0): A Social Innovation Perspective. Technology Innovation Management Review, 7(11), 12-20. https://doi.org/10.22215/timreview/1117

Newman, W. L. (2014). Social Research Methods: Qualitative and Quantitative Approaches (7th ed.). Essex: Pearson Education Limited.

OECD/International Telecommunication Union. (2011). M-Government: Mobile Technologies for Responsive Governments and Connected Societies, (OECD Publishing.doi: 10.1787/9789264118706-en).

Prabowo, T. L., \& Irwansyah, I. (2018). Media Komunikasi Digital PolisiKu: Pelayanan Publik Polri kepada Masyarakat. Jurnal Studi Komunikasi (Indonesian Journal of Communications Studies), 2(3), 382. https://doi.org/10.25139/jsk.v2i3.1174

Rachna, B., Khajuria, I., $\alpha$, R., \& Khajuria $\sigma$, I. (2017). A Study of User-Generated Content on Social Networking Sites and its Impact on Consumer-Based Brand Equity Constructs. Type: Double Blind Peer Reviewed International Research Journal Publisher: Global Journals Inc, 17(1). Retrieved from https://globaljournals.org/GJMBR_Volume17/1-A-Study-of-UserGenerated.pdf

Ruggiero, T. E. (2017). Uses and Gratifications Theory in the 21st Century, (February 2000), 2-38. https://doi.org/10.1207/S15327825MCS0301

Sharma, M., \& Thakur, A. (2014). Review Paper on Android Operating System, 658-664.

Soegiono, A. N. (2017). Agenda Open Government Memerangi Korupsi Melalui Inisiatif Open Data. Integritas, $3(2), \quad 1$. https://doi.org/10.32697/integritas.v3i2.98

Sukadari, Komalasari, M. D., \& Wihaskoro, A. M. (2018). Efektivitas Penanaman Nilai Integritas pada Siswa SD melalui Buku Wayang Pandawa Bervisi Antikorupsi. Jurnal Integritas, 4(1), 217-244. 
Ipi Maryati Kuding, Irwansyah: Pemanfaatan Ragam Aplikasi Seluler Antikorupsi dalam Upaya Pencegahan Korupsi

Tracy, K. W. (2012). Mobile application development experiences on Apples iOS and Android OS. IEEE Potentials, 31(4), 30-34. https://doi.org/10.1109/MPOT.2011.2182571

West, D. M. (2014). Going Mobile: How Wireless Technology is Reshaping Our Lives. Brookings Institution Press. Retrieved from https://books.google.co.id/books?id=HE2aBAAAQBAJ

Wong, S. H. R. (2012). Which platform do our users prefer: Website or mobile app? Reference Services Review, 40(1), 103-115. https://doi.org/10.1108/00907321211203667 